ISIDORIANUM 24/47-48 (2015) 9-12

\title{
PRESENTACIÓN DE D. JOSÉ ARTURO DOMÍNGUEZ ASENSIO
}

\author{
Ramón Valdivia Giménez \\ Director del Centro de Estudios Teológicos de Sevilla
}

Para un servidor es un verdadero honor el poder hacer una laudatio en este número - homenaje de la revista del Centro de Estudios Teológicos Isidorianum al profesor José Arturo Domínguez Asensio.

El profesor Dominguez Asensio nace en Riotinto (Huelva) el 8 de agosto de 1943, ingresa en el Seminario de Huelva en el 1960. Estudia Teología en la Universidad Pontificia de Salamanca. Y comienza su larga experiencia docente en el curso 68-69 en el Seminario Huelva. En el curso 1971-72 imparte su primer curso en el Centro de Estudios Teológicos de Sevilla, fundado dos años antes. Es llamado para proseguir sus estudios como Becario de la Iglesia Nacional Española en Monserrat. Se doctora en Sagrada Teología, bajo la dirección del P. Joseph Becker, hoy cardenal, con el tema: Infalibilidad y determinatio de fide en la teología del cardenal Cayetano. Desde el año 1975 - 2014 profesor en el Centro de Estudios Teológicos de Sevilla y en el Seminario de Huelva. Canónigo Magistral de la Catedral de Huelva y Párroco de la de San Pedro en la ciudad de Huelva. Autor de publicaciones y conferencias, así como teólogo miembro de la Pontifica academia Mariana Internacional.

En el CET ha dado clases en diversas materias como Eclesiología y Ecumenismo, Mariología, Escatología, Trinidad, Sacramentos y Metodología Teológica, Introducción a la Teología, Pneumatología y otras. 
Si hubiera que describirlo, creo que el más acertado es el de Maestro, quien ha consolidado su auctoritas desde la sabiduria y la búsqueda de la verdad. D. José Arturo ha tenido la capacidad de maniobrar con destreza, durante cuarenta generaciones el alma de sus discípulos, llevándolos a través de imágenes accesibles de la potencia cognoscitiva al acto del conocimiento, según lo define Santo Tomás.

En la lectio que pronunciara nuestro querido profesor en la Inauguración del curso académico del CET del curso 2015-2016 titulada La enseñanza de la Teología: mirada a un pasado iluminador del presente. Método teológico en la Escuela de Salamanca reivindicó para el Claustro de profesores y alumnos lo que ha ejercido durante tantos años dando lustre y prestigio con su presencia a nuestro Centro. Previamente, tuve la dicha de presentarlo en ese entrañable acto académico, en el que destaqué tres enseñanzas que recuerdo de su magisterio.

La primera de las frases que recuerdo, a vuelapluma, es todo un clásico: Lean ustedes menos revistas divulgativas y más la Palabra de Dios. Se refería a la moda, parece que perenne, de reducir la teología a aquellas publicaciones, entonces en papel y hoy en internet, chismosas que tratan sobre las cosas de las gentes que están alrededor de Dios, pero que no son Dios. La teología es otra cosa, y nuestro querido profesor nos lo subrayaba desde el comienzo de sus clases. La Palabra de Dios es el contenido esencial de la Teología, es más, es Dios el contenido mismo de la teología, más que la mera acción fosilizada de las meraviglia Dei. D. José Arturo ha dedicado, y espero que siga dedicando, su vida al conocimiento de ese Dios que, como señalaba el cardenal Newman habla al corazón de los hombres y los despierta del letargo con su dulce Palabra, que encarnada, quiere acompañar con su presencia el camino de los hombres hasta llevarlos a su destino. El teólogo es el hombre que se ha dejado provocar por la Palabra, y trata de balbucear con su razón y la fe, el hermoso rostro de quien ha decidido comunicarSe y decirSe en la Persona de Jesucristo. D. José Arturo, con su enseñanza no hacía teología como un pasado arqueológico hermoso, pero ausente; sino que nos hacía presente Su presencia, el rostro de Aquel por el que los hombres suspiran cuando desean ser amados. 
La segunda proposición no es menos teológica: El jamón de la Sierra de Huelva es exquisito, pero no sirve para Consagrar. Además de las clases de teología, el profesor Dominguez Asensio, encarnado en su tierra, despertaba el interés culinario de la Sierra de Huelva, desde el corte selecto de los cuartos traseros del cerdo, hasta el gustoso sabor de los gurumelos. Este interés por la comida no tendría sentido si el hombre no hubiera podido saborear a Dios. En efecto, así como las recetas más exquisitas requieren la obediencia de la cocina transmitida de generación en generación, así la teología no ha podido ni podrá jamás, cocinar con su libre albedrío la Presencia de Dios, porque ante Dios solo cabe la obediencia de la fe, ya que sólo en Dios se encuentra el Amor que hace libre al hombre. Por eso, sus lecciones no sólo abrían el apetito, sino el delicado espíritu de los alumnos, quienes, fides ex auditu, recibían de él y con él, el influjo del olor de la Verdad que nos atraía con razones adecuadas al intelecto y atrayentes a la libertad. Como verdadero alimento, que sacia con Su divinidad el corazón de una communio que es Pueblo y Cuerpo de Cristo, la Eucaristía hace la Iglesia, cuyo verdadero origen no es la voluntad de los participantes, sino la voluntad de Dios de congregarnos con su Palabra y su alimento hasta la vida eterna.

La tercera proposición es: Ahora cualquiera se pone bajo su nombre el título de teólogo, cuando el único teólogo fue el Apóstol San Juan. Y es que, frente a quien trata de profesionalizar la teología como una ciencia entre las otras, nuestro profesor ha reivindicado que el verdadero testigo fiel de Dios ha sido la expresión humana de la voluntad divina: Jesucristo, el Hijo de María, Inmaculada. Frente a un papel frío y distante del observador científico, aparece la necesidad del testigo, como hace el apóstol San Juan: "Nuestros ojos han visto y nuestras manos han tocado al Verbo de la Vida». Por ello, reclama para el teólogo haber conocido y amado al Señor, tratado en intimidad con Él; haber comido y vivido la Pascua junto a Él. Es necesaria la experiencia del Misterio salvador de la Cruz y de la Resurrección, sin el cual el hombre es sólo un mero observador. Por eso, la humildad es el origen de todo verdadero conocimiento, sea filosófico, como teológico.

Y, a manera de Epílogo, quisiera señalar una última anécdota personal como la que me indicó el primer día tras mi elección como 
director del CET: Para lo que de verdad sirve el director del CET es para poner café en la sala de profesores. Y es que el oficio de la teología no es una elucubración solipsista de quien no tiene oficio técnico o manual, como diría Aristóteles, sino que tiene una marcada misión eclesial que es la del Servicio de la fe. D. José Arturo, ha servido constante y fielmente a la fe en Andalucía. Ha recorrido incansablemente año tras año, hasta cuarenta, las carreteras de nuestras provincias para proclamar, como San Pablo, el Evangelio de Jesucristo. El servicio que ha dado a nuestra Archidiócesis ha sido encomiable. Estoy convencido que en su interior, ha recibido esta misión y la ha llevado a cabo más allá de sus propias fuerzas, porque ha sido el mismo Cristo quien se ha servido de D. José Arturo para mostrarnos Su rostro, por esto y por tantas otras cosas, no nos queda más que decir:

Gracias D. José Arturo. 